\title{
Preparation and scaling up of a low phenylalanine enzymatic hydrolysate of bovine whey proteins
}

\author{
Marilisa Guimarães Lara ${ }^{1}$, Clarice Izumi ${ }^{2,3}$, Lewis Joel Greene ${ }^{2,3}$, Luciano Vilela, ${ }^{4}$ \\ Osvaldo de Freitas ${ }^{1, *}$
}

\begin{abstract}
'Departamento de Ciências Farmacêuticas, Faculdade de Ciências Farmacêuticas de Ribeirão Preto, Universidade de São Paulo, ${ }^{2}$ Centro de Química de Proteínas and ${ }^{3}$ Departamento de Biologia Celular, Molecular e Bioagentes Patogênicos, Faculdade de Medicina de Ribeirão Preto, Universidade de São Paulo, ${ }^{4}$ Biomm, Montes Claros,
\end{abstract} Minas Gerais, Brazil

"Correspondence:

O. Freitas

Departamento de Ciências

Farmacêuticas

Faculdade de Ciências Farmacêuticas

de Ribeirão Preto

Universidade de São Paulo

Av. do Café $\mathrm{s} / \mathrm{n}$

14040-903 - Ribeirão Preto -SP, Brazil

E-mail: ofreitas@fffrp.usp.br
We describe the preparation of pancreatic enzymes hydrolysate of milk whey proteins containing low levels of aromatic amino acids. Pancreatin and trypsin/chymotrypsin ( $6.3 \% \mathrm{w} / \mathrm{w}$ protein) when used to hydrolyze whey proteins for $27 \mathrm{~h}$ at $37 \pm 2{ }^{\circ} \mathrm{C}$, released $74 \%$ of the Phe, $100 \%$ of the Tyr and $100 \%$ of the Trp as free amino acids. Most of the free aromatic amino acids present in $2 \mathrm{~kg}$ hydrolysate were separated from the remaining peptides and other amino acids by gel filtration on a 15 liter Sephadex G-25 column eluted with 5\% acetic acid at 60 liters $h$ ${ }^{I}$ at $25^{\circ} \mathrm{C}$. The product, recovered in $37 \%$ yield, contained $0.70 \mathrm{mmol}$ Phe, $0.41 \mathrm{mmol} \mathrm{Tyr}$, and $<0.01 \mathrm{mmol}$ Trp $/ 100 \mathrm{mmol}$ recovered amino acids. The hydrolysate had a general amino acid composition similar to the whey proteins from which it was prepared and could be used as a nitrogen source for patients with phenylketonuria or tyrosinemia after the addition of appropriate aromatic amino acids.

\section{INTRODUCTION}

The hyperphenylalaninemias are a subclass of a genetic disease complex referred to inborn errors of metabolism. Phenylketonuria (PKU) is the most common hyperphenylalaninemia. It is characterized by high levels of phenylalanine (Phe) in the blood and massive excretion of its metabolites, due to a deficiency of hepatic phenylalanine hydroxylase which converts Phe to tyrosine. Classical PKU untreated children require costly financial and social institutionalization due to irreversible neurological damage (Cleary et al., 1994) manifested clinically as mental retardation (Scriver, Kaufman, Woo, 1989).
The available and effective treatment for classical PKU is the dietary restriction of Phe (Freitas et al., 1999; Bowersox, 2001). The efficacy of classical PKU therapy with low-Phe diet, when used early in infancy has been amply documented (Grever et al., 1994; Blau \& Scriver, 2004). However, diets should contain small and controlled amounts of Phe to maintain the normal development of children with PKU (Smith, 1994) since Phe is necessary for the synthesis of protein and neurotransmitters.

Commercial products available for the treatment of PKU can be classified into two categories of protein substitutes: oligomeric diets, composed of protein hydrolysates, Phe-free or with reduced content, and 
monomeric diets, composed of a balanced mixture of free synthetic amino acids, completely lacking Phe (Scriver $e t$ al., 1989; Rohr, Munier, Levy, 2001).

Casein and whey proteins are the most important sources used in the development of protein hydrolysates for patient nutrition due to an adequate amino acid composition, large scale commercial availability and moderate cost (Clemente, 2000). However, since they are proteins rich in Phe (2.4-9.0\% by weight)(Elsas \& Costa, 1994), post-hydrolysis procedures are necessary to eliminate aromatic amino acids before using as a nitrogen source in diets for PKU patients. There are only a few descriptions of low Phe protein hydrolysates in the literature (Nakhost et al., 1982; Arai et al., 1986; Vasconcelos et al., 1989; Lopez-Bajonero et al., 1992) and none on a pilot plant or industrial scale.

In the present work, we describe a process for the preparation of an enzymatic hydrolysate of bovine whey proteins with low Phe levels, appropriate for use as a nitrogen source in diets for PKU patients. The characterization of the protein hydrolysate, in terms of amino acid composition, will also be described and discussed in relation to its possible use in the formulation of specialized low-Phe medical foods for the treatment of PKU patients.

\section{MATERIAL AND METHODS}

\section{Material}

Bovine milk whey proteins were obtained from a commercial source in New Zealand and contained 80.9\% protein. Its major protein components were D-lactalbumin and E-lactoglobulin. The porcine pancreatic proteolytic enzymes (pancreatic extract containing trypsin, chymotrypsin, carboxypeptidases A and B, lypases and amylases, 100 USP units of protease activity $\mathrm{mg}^{-1}$ ), Proteomix ${ }^{\circledR}$, a mixture of bovine and porcine trypsin (2000 USP units mg$\left.{ }^{1}\right)$ and a mixture of bovine and porcine chymotrypsin (400 USP units $\mathrm{mg}^{-1}$ ), were products from Biobrás S.A. (Montes Claros, MG, Brazil). Sephadex G-25F for the analytical column and G-25C for the preparative column were purchased from Pharmacia (Uppsala, Sweden). Reagents for amino acid analyses, the Standard $\mathrm{H}$ amino acid mixture, and individual amino acids were obtained from Pierce Chemical Co. (Rockford, IL, USA). All other chemicals were of reagent grade or equivalent.

\section{Preparation of whey protein hydrolysates}

The conditions for the preparation of three analytical scale hydrolysates which differ in enzyme content and digestion time, and one pilot scale hydrolysate are reported in Table I. For the analytical scale procedure whey protein dispersed in water $(10 \%, \mathrm{w} / \mathrm{v})$ was hydrolyzed using a $\mathrm{pH}$ stat in a volume of $250 \mathrm{~mL}$ at $37-40^{\circ} \mathrm{C}$, the $\mathrm{pH}$ being kept at 7.5-8.0 by additions of ammonium hydroxide. The reaction was stopped by heating to the boiling point for 30 min. After cooling the hydrolysate was clarified by filtration and lyophilized. Enzyme quantities were reported as percent $(\mathrm{w} / \mathrm{w})$ relative to whey protein in parentheses, followed by incubation time are as follows: Hydrolysate A1: pancreatin $(1.8 \%, \mathrm{w} / \mathrm{w})$ and $\operatorname{Proteomix}^{\circledR}(0.3 \%, \mathrm{w} / \mathrm{w})$; the total amount of enzyme was added at time $0 \mathrm{~h}$ and incubated for $9 \mathrm{~h}$. Hydrolysate A2: pancreatin $(3.6 \%, \mathrm{w} / \mathrm{w})$

TABLE I - Conditions and recovery data in the preparation of analytical and pilot plant level whey protein enzymatic hydrolysates .

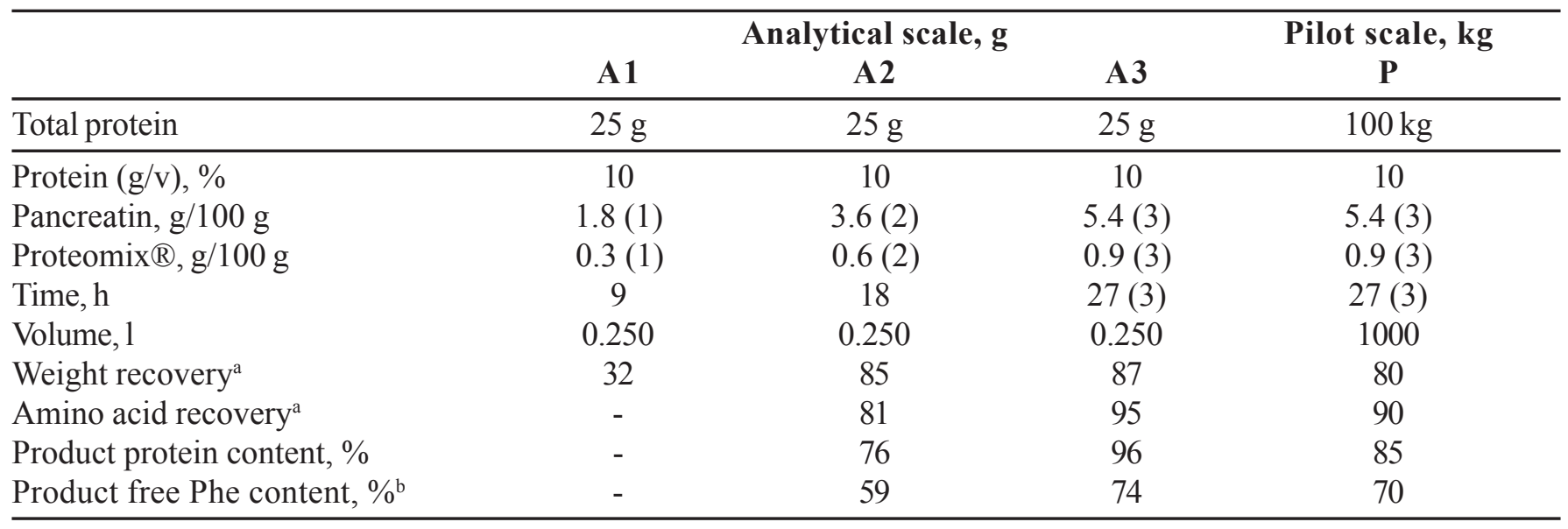

Recovery of soluble material and recovery of amino acids after enzymatic hydrolysis, clarification and lyophilization or spraydrying . ${ }^{\text {FFee }}$ Phe $(\%)=$ moles free Phe $\times 100$ /total moles Phe total $\times 100$. - = not determined, due to low recovery. 
and Proteomix ${ }^{\circledR}(0.6 \%, \mathrm{w} / \mathrm{w})$; each half of the total amount of enzyme was added at 0 and $9 \mathrm{~h}$, respectively; the total time of incubation was $18 \mathrm{~h}$. Hydrolysate A3: pancreatin $(5.4 \%, \mathrm{w} / \mathrm{w})$ and Proteomix ${ }^{\circledR}(0.9 \%, \mathrm{w} / \mathrm{w})$; each one-third of the total amount of enzyme was added at 0,9 and $18 \mathrm{~h}$, respectively; the total time of incubation was $27 \mathrm{~h}$. There are 3 fold differences in the amount of enzymes and incubation time when $\mathrm{A} 1$ is compared to A3, with A2 occupying an intermediate position in terms of the intensity of hydrolytic conditions. In pilot scale hydrolysis, conducted in a $1000 \mathrm{~L}$ reactor, we utilized the same conditions of the hydrolysate $\mathrm{A} 3$; $\mathrm{pH}$ was monitored and corrected each two hours. The final dispersion was spray-dried.

\section{Amino acid analyses}

Qualitative and quantitative amino acid composition of intact protein and hydrolysates was determined after acidic hydrolysis by cation exchange (PC-6AAmino acid analysis resin, Pierce Chemical Co., Rockford, Il, USA) chromatographic fractionation, and detection by post-column derivatization with ninhydrin, as described by Spackman, Stein, Moore (1958), using an automatic amino acid analyzer (Alonzo, Hirs, 1968). The analyzer consisted of a short $(0.6 \times 17 \mathrm{~cm})$ and a long column $(0.6 \times 42 \mathrm{~cm})$, for the separation of basic (short column), neutral and acidic amino acids (long column). Chromatographic fractionation was developed using sodium citrate buffers with different $\mathrm{pHs}$ and ionic strengths and the eluate was treated with ninhydrin solution for $10 \mathrm{~min}$ in a boiling water. After derivatization, the products were detected by spectrophotometry; 440 and 570 $\mathrm{nm}$ was used for detection of proline and other amino acids, respectively. The system was standardized to operate in a sensitivity range of 1-10 $\mathrm{n} M$, using an amino acid standard solution (Pierce $\mathrm{H}$ ), containing $5.0 \mathrm{n} M$ of each amino acid. The identification of amino acids was made by retention time and the quantification by peak height in relation to a constant (concentration/peak height of standard).

Total amino acids was determined after hydrolysis of 1-2 mg of samples (intact protein or enzymatic hydrolysates) for 22 hours at $110{ }^{\circ} \mathrm{C}$ in $0.500 \mathrm{~mL}$ of constant boiling $6 \mathrm{~N}$ $\mathrm{HCl}$ containing $0.01 \%$ phenol in an evacuated sealed tube. Tryptophan (Trp) was determined after hydrolysis of 3-5 mg of samples (protein or enzymatic hydrolysate) with $4 \mathrm{~N}$ $\mathrm{LiOH}$ (Lucas, Sotello, 1980). No corrections were made for losses of methionine, cysteine, serine, threonine or tyrosine (Tyr) during acid hydrolysis. Amino acid hydrolysis and analysis were made in duplicate, with an acceptable variation of $8 \%$ between each duplicates.

The same method was used to measure free amino acids in samples not submitted to acidic hydrolysis. Small peptides were distinguished from free amino acids by peak width and the ratio of absorbance at 570 to $440 \mathrm{~nm}$ in the elution profiles

\section{Yields and recovery calculations}

The yield of the process was determined by the ratio of weight of product (hydrolysate) recovered after enzymatic hydrolysis and drying to the initial weight of intact protein.

The ratio of total amount of amino acids ( $\mu$ moles $/ \mathrm{mg}$ ) determined in the enzymatic hydrolysate after drying to the total amino acids determined in the intact protein (not submitted to enzymatic hydrolysis) was considered as amino acid recovery.

Total protein content (in $\mathrm{mg}$ ) was calculated based on amino acid analyses, i.e., as the values in sum of the $\mu$ moles of each amino acid was multiplied by the corresponding molecular weight minus one water molecule. Total amino acids in mg was calculated by the sum of weights of each individual $\mathrm{mg}$ of amino acid. The ratio between total $\mathrm{mg}$ of amino acids and $\mathrm{mg}$ to and $\mathrm{mg}$ of sample submitted to amino acid analysis multiplied by 100 was considered as the protein content in the sample.

\section{Gel filtration}

The free aromatic amino acids and other amino acids and peptides in the hydrolysates were separated after gel filtration on a Sephadex G-25 column developed at $22^{\circ} \mathrm{C}$ with $5 \%$ acetic acid (v/v), as described by Freitas et al. (1993). In analytical experiments $100 \mathrm{mg}$ hydrolysate, in $2.5 \mathrm{~mL}$ of $5 \%$ acetic acid containing $1 \mathrm{MNaCl}$, was applied to a $0.9 \times 250 \mathrm{~cm}$ Sephadex G25F column operated at $1.0 \mathrm{~mL} \mathrm{~min}^{-1}$ and fractions of $1.6 \mathrm{~mL}$ were collected. $\mathrm{NaCl}$ was included in the sample solution to prevent electrostatic interactions of positively charged peptides or amino acids with a small amount of carboxyl groups which may have been present due to the oxidation of the resin and to produce comparative profiles by fixing the elution volume.

Solutes were detected in the effluent by absorbance at $280 \mathrm{~nm}$ (amino acids and peptides containing aromatic amino acids) and by conductivity at $22{ }^{\circ} \mathrm{C}$ in a 1:50 dilution of the effluent in distilled water $(\mathrm{NaCl})$. The fractions were combined into pools based on the elution profile as described by Freitas et al. (1993) and indicated below the elution profile give in Figure 1B.

The pilot scale gel filtration of $2 \mathrm{~kg}$ of hydrolysate was carried out in a $25 \times 103 \mathrm{~cm}$ Sephadex G-25C column. The sample was applied in a volume of 15 liters in 5\% (v/v) acetic acid and the column eluted with the same solvent at 


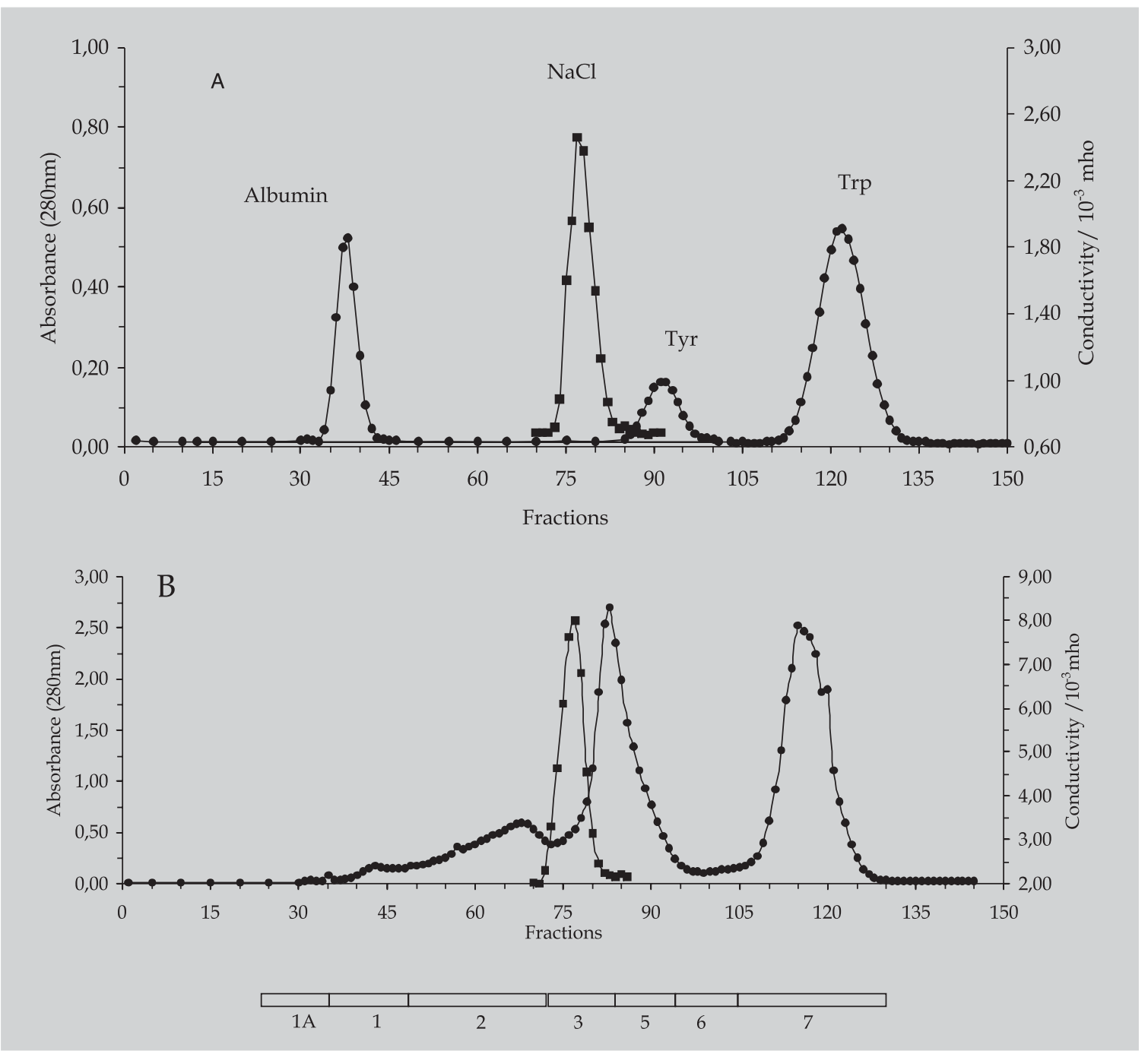

FIGURE 1 - Analytical gel filtration chromatography of a whey protein enzymatic hydrolysate. The Sephadex G-25F column $(0.9 \times 250 \mathrm{~cm})$ was eluted at $10 \mathrm{ml} / \mathrm{h}$ at $22{ }^{\circ} \mathrm{C}$ with $5 \%(\mathrm{v} / \mathrm{v})$ acetic acid $\mathrm{pH} 2.5$, and $1.6 \mathrm{ml}$ fractions were collected. Samples were applied in $3.0 \mathrm{~mL}$ aliquots of $5 \%$ (v/v) acetic acid. The effluent was monitored by absorbance at $280 \mathrm{~nm}$ (closed circles) and by conductivity measurements (closed squares). Panel A: Elution of the calibration mixture containing $6 \mathrm{mg}$ of bovine serum albumin, $1.6 \mu \mathrm{mol}$ tyrosine, $1.5 \mu \mathrm{mol}$ triptofane, and $1 \mathrm{mmol} / \mathrm{ml} \mathrm{NaCl}$. Panel B: elution of a sample containing $100 \mathrm{mg}$ of hydrolysate A3. Tyr = tyrosine, Trp = Tryptophan.

60 liters $\mathrm{h}^{-1}$. One liter fractions were collected, combined into pools based on the elution profile, as indicated below the elution diagram (in Figure 2) and spray-dried.

\section{RESULTS AND DISCUSSION}

\section{Release of free Phe from whey proteins}

Table I describes the experimental hydrolysis conditions, i.e. quantity of pancreatic proteolytic enzymes and incubation times carried out on three analytical scale procedures, (25g whey protein, A1 to A3) and the use of the most stringent conditions (A3) on a pilot plant scale (P, $100 \mathrm{~kg}$ whey protein). Some characteristics of the soluble fraction obtained after clarification of the hydrolysate are also given in Table I. Large amounts of the enzymes tested $(6.3 \% \mathrm{w} / \mathrm{w})$ were required to obtain the highest recovery of product by weight and in terms of amino acid content the highest amount of free Phe release (74\%). When some of the conditions used for hydrolysate A3 were applied to $100 \mathrm{~kg}$ whey protein, the product was obtained in $90 \%$ yield, with characteristics similar to those obtained on the $25 \mathrm{~g}$ analytical scale and with $70 \%$ of its Phe in the free amino acid form. 


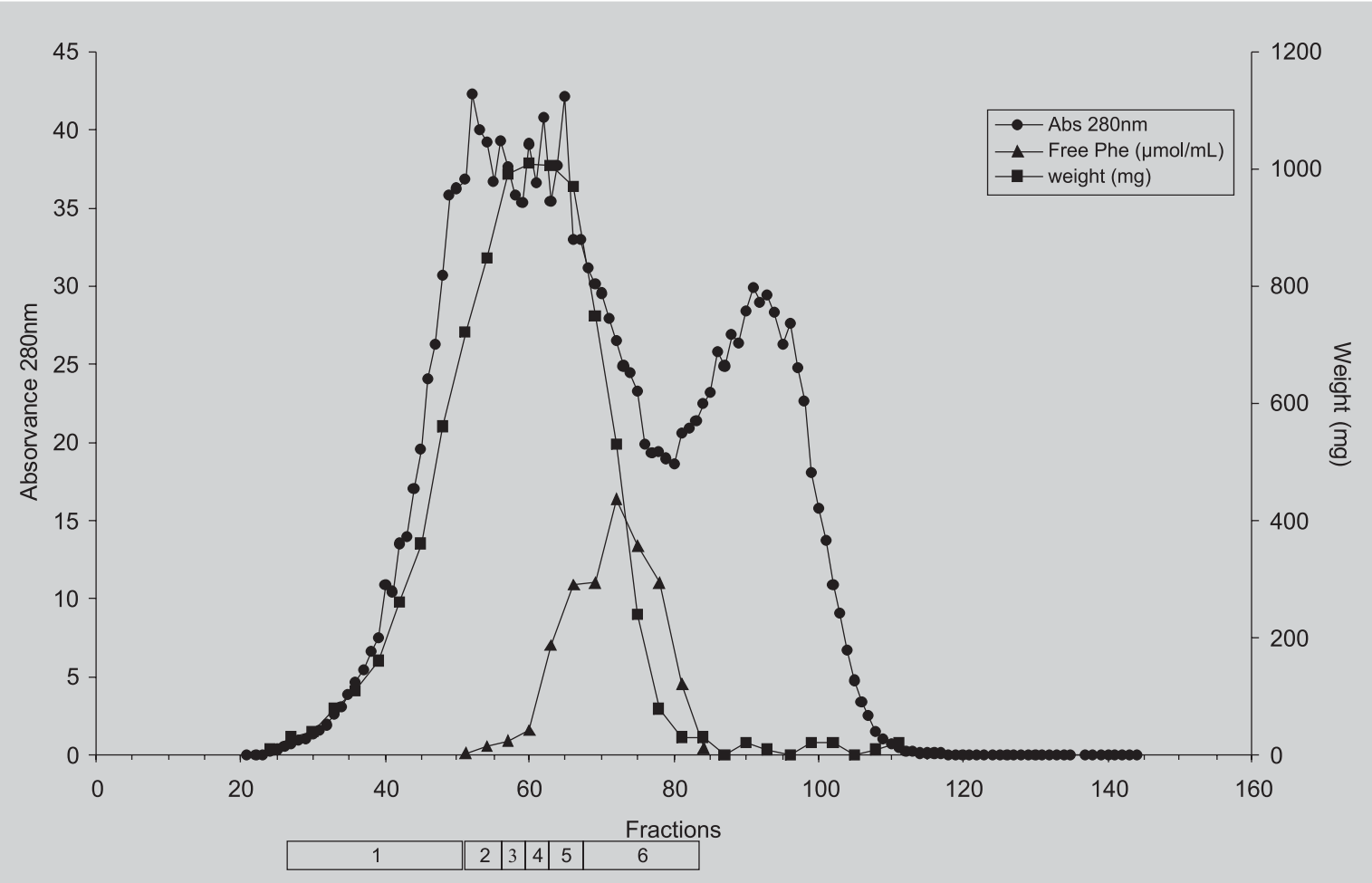

FIGURE 2 - Pilot scale gel filtration chromatography of whey protein enzymatic hydrolysates. The Sephadex G-25F column $(25.2 \times 103 \mathrm{~cm})$ was equilibrated and eluted at 60 liters $/ \mathrm{h}^{-1}$ at $22{ }^{\circ} \mathrm{C}$ with $5 \%(\mathrm{v} / \mathrm{v})$ acetic acid pH 2.5, and 1 liter fractions were collected. The hydrolysate $\mathrm{P}(2.0 \mathrm{~kg})$ was applied in 15 liters of $5 \%(\mathrm{v} / \mathrm{v})$ acetic acid. The effluent was monitored by absorbance at $280 \mathrm{~nm}$ (closed circles). The curve represented by closed squares shows the amount of material recovered $(\mathrm{mg})$ after lyophilization of $10 \mathrm{ml}$ of each fraction. The tracing represented by closed triangles shows the amount of free Phe $(\mu \mathrm{mol} / \mathrm{ml})$ present in the fractions as determined by amino acid analyses.

The selection of suitable enzymes to produce hydrolysates with defined physicochemical and nutritional characteristics is essential (Clemente, 2000). Arai (1986) used a pepsin-pronase system on whey proteins and Lopez-Bajonero et al. (1992) used the protease 2A from Aspergillus oryzae and papain to hydrolyse casein. Pancreatin supplemented with chymotrypsin were used in our experiments because they provide the complementary pairs, endopeptidase/ exopeptidase, chymotrypsin/carboxypeptidase A, which when acting in series can release free aromatic amino acids from proteins if proline is not adjacent to the aromatic amino acid (Ambler, 1967). When casein was treated under similar conditions only $50 \%$ of the Phe was released (See Hydrolysate C, Freitas et al., 1993) and when pancreatic tissue was used as the source of proteolytic enzymes, the release of all free amino acids was increased by $50 \%$ but the release of Phe increased by only $8 \%$, from 50 to $54 \%$ (unpublished data from our laboratory). The inability to release more Phe as the free amino acid from bovine casein is due to the presence of the sequences ProPhePro and ProPhe which account for $29 \%$ of the Phe present in casein. In contrast, neither bovine lactoglobulin nor lactoalbumin contain the sequences ProPhePro or ProPhe (Dayhoff, 1972).

\section{Removal of free Phe from the hydrolysate and characterization of the low-Phe hydrolysate}

The development of protein hydrolysates for patients with PKU necessarily includes post-hydrolysis procedures to remove free Phe. Gel filtration on Sephadex G-25 (Nakhost et al., 1982; Arai, 1986) or on BioRad G-10 and adsorption to hydrophobic resins (Vasconcelos et al., 1989) have been used in analytical experiments to separate aromatic amino acids from other components present in the enzymatic hydrolysates. Treatment by activated carbon (Lopez-Bajonero et al., 1992) or the use of ionic exchange resins have also been described (Heindorff et al., 1988; Matsuo, Hashimoto, Arai, 1986).

We have used a $0.9 \times 250 \mathrm{~cm}$ Sephadex G-25 analytical column as described by Freitas et al. (1993) to separate free aromatic amino acids from the whey 
hydrolysate. The data in Figure 1A shows that both Tyr and Trp are eluted after $\mathrm{NaCl}$ under these conditions. Phe was eluted between $\mathrm{NaCl}$ and $\mathrm{Tyr}$ (data not shown).

The elution diagram obtained for hydrolysate $\mathrm{A} 3$ is shown in Figure 1B indicating the absorbance profile at 280 $\mathrm{nm}$ and the conductivity measurements of the effluent. Most of the recovered peptides and free amino acids $(80 \%)$ were eluted before the $\mathrm{NaCl}$ and present in pools 1 and 2 (indicated by the bars below the elution diagram).

Data shown in Table II indicate that the general amino acid composition of hydrolysate A3 did not differ significantly from that of the whey protein from which it was prepared (compare column 1 with column 3 ). We assume the losses of Tyr and Trp were due to their low solubility, but cannot explain the differences in the loss of Arg and over recovery of Val. Gel-filtration removed $100 \%$ of the Trp, $89 \%$ of the Tyr and $75 \%$ of the Phe present in the hydrolysate. The aromatic amino acids remaining in the bulk of the hydrolysate were present in peptides and not free. The product, A3 after gel filtration, contained $0.73 \mathrm{~mol} \%$ Phe which corresponds to $9.2 \mathrm{mg}$ Phe/g total protein.

As expected, high efficiency of the separation of the aromatic amino acids obtained with the $0.9 \mathrm{u} 250 \mathrm{~cm}$ analytical column could not be obtained with the shorter $25.2 \mathrm{u} 103 \mathrm{~cm}$ Sephadex G-25 pilot scale column used for the gel filtration of $2 \mathrm{~kg}$ of whey hydrolysate. The data in Figure 2 shows that the protein was recovered in fractions 20 to 80 corresponding to the first $\mathrm{A}_{280 \mathrm{~nm}}$ peak. The second $\mathrm{A}_{280 \mathrm{~nm}}$ peak contains Tyr and Trp. The elution of free Phe (indicated by the triangles) peaks at fraction 75 indicates that at least $50 \%$ of the recovered hydrolysate is essentially Phe-free.

The Phe content of $0.70 \mathrm{~mol} \%$ corresponds to $9.0 \mathrm{mg}$ $\mathrm{Phe} / \mathrm{g}$ total protein. Lofenalac, a product based on low-Phe enzymatic casein hydrolysate available in the market for dietary treatment of PKU patients, contains $75 \mathrm{mg}$ Phe/ $100 \mathrm{~g}$ product (Clemente, 2000). Thus the low-Phe fraction described here could be used, with appropriate addition of free amino acids, in the formulation of low-Phe diets suitable for the treatment of PKU patients; in this case, tyrosine and triptophan should be added to the resulting diet to avoid impairment of its nutritional quality.

The analytical and pilot scale processes described in the present work produced a 70-74\% reduction in Phe levels compared to the starting material (whey proteins), yielding

TABLE II - Amino acid composition of the protein source (whey protein), the A3 hydrolysate, its fraction obtained by combining pools 1 and 2 and of the pilot level hydrolysate $\mathrm{P}$ and the fraction with low Phe.

\begin{tabular}{lccccc}
\hline Amino acid & $\begin{array}{c}\text { Whey } \\
\text { protein }\end{array}$ & $\begin{array}{c}\text { Analytical scale experiment } \\
\text { Hydrolysate } \\
\text { Fraction pools }\end{array}$ & $\begin{array}{c}\text { Pilot scale experiment } \\
\text { Hydrolysate } \\
\text { P }\end{array}$ & $\mathbf{1 + 2}$ & $\begin{array}{c}\text { Fraction low } \\
\text { Phe }\end{array}$ \\
\hline & & 2 & 3 & 4 & 5 \\
Trp & 1 & 1.17 & $<0.01$ & 1.15 & $<0.01$ \\
Lys & 1.55 & 9.24 & 11.71 & 9.11 & 9.18 \\
His & 8.48 & 1.93 & 2.17 & 1.92 & 2.05 \\
Arg & 1.64 & 0.35 & 0.42 & 2.85 & 1.63 \\
Asp & 2.12 & 9.61 & 11.36 & 11.05 & 12.27 \\
Thr & 10.32 & 5.24 & 6.14 & 5.69 & 6.07 \\
Ser & 5.59 & 5.41 & 6.45 & 6.02 & 6.55 \\
Glu & 5.68 & 12.32 & 15.46 & 14.82 & 17.72 \\
Pro & 13.79 & 5.85 & 7.08 & 6.19 & 7.54 \\
Gly & 5.63 & 4.45 & 4.98 & 3.88 & 4.12 \\
Ala & 3.81 & 8.86 & 10.13 & 7.88 & 8.00 \\
Cys & 8.15 & 1.91 & 2.99 & 2.07 & 2.52 \\
Val & 2.73 & 7.23 & 7.99 & 6.32 & 6.10 \\
Met & 2.47 & 2.27 & 1.68 & 1.96 & 1.77 \\
Ile & 2.19 & 6.02 & 6.01 & 4.79 & 4.43 \\
Leu & 4.57 & 13.81 & 4.40 & 11.11 & 8.95 \\
Tyr & 12.53 & 1.16 & 0.30 & 1.55 & 0.41 \\
Phe & 2.79 & 3.20 & 0.73 & 2.72 & 0.70 \\
\hline
\end{tabular}

The data are reported as moles of amino acids/ 100 moles of total recovered amino acids 
a high protein ( $\sim 90 \%)$ and a low Phe ( $\sim 9 \mathrm{mg} / \mathrm{g}$ total protein) product. The general amino acid composition of the fractions described in our work was similar to that of the protein source, except for the aromatic amino acids, in both procedures (analytical and pilot level), demonstrating that the scale-up of these processes was effective and viable. Our results indicated also that the selective enzymatic hydrolysis and not the post-hydrolysis processing is the limiting step in the process of obtaining protein hydrolysates with low-Phe level. However, the low-Phe hydrolysate described in our work could still be used in the composition of medical foods for treatment of PKU or tirosemia patients.

\section{RESUMO}

\section{Preparação e escalonamento de um hidrolisado enzimático de proteínas do soro de leite bovino}

Foi descrita a preparação de um hidrolisado de proteinas do soro de leite bovino com enzimas pancreáticas, contendo baixos niveis de aminoácidos aromáticos. Quando utilizadas pancreatina e tripsina/quimotripsina, por $27 \mathrm{~h}$ a $37 \pm 2^{\circ} \mathrm{C}$, foram liberados $74 \%$ de Phe, $100 \%$ de Tyr e 100\% de Trp como aminoácidos livres. A maioria dos aminoácidos aromáticos livres, presentes em dois quilos de hidrolisado (15 litros), foi separada dos peptídeos e outros aminoácidos remanescentes por filtração em coluna de gel de Sephadex G25 C eluida com ácido acético $5 \%$, fluxo de 60 litros por hora a $25^{\circ} \mathrm{C}$. O produto, recuperado com $37 \%$ de rendimento, continha 0,70 mmol de Phe, 0,41 mmol de Tyr $e<0,01 \mathrm{mmol}$ de Trp/100 mmol de aminoácidos recuperados. A composição em aminoácidos do hidrolisado foi similar às proteínas do soro com as quais foi preparado. Após adição de aminoácidos aromáticos apropriados, ele pode ser usado como fonte de nitrogênio para pacientes com fenilcetonuria ou tirosinemia.

Unitermos: Dieta pobre em fenilalanina. Fenilcetonúria. Tirosinemia. Hidrolisado de proteína de soro de leite. Hidrolisado de pancreatina. Filtração em gel.

\section{ACKNOWLEDGEMENT}

This research was supported by grants from FINEP-FNDCT (Financiadora de Estudos e Projetos Fundo Nacional de Desenvolvimento Científico e Tecnológico), CNPq/Pronex (Conselho Nacional de Desenvolvimento Científico e Tecnológico - Programa de Apoio a Núcleos de Excelência), and CAPES (Coordenação de Aperfeiçoamento de Pessoal de Nível Superior).

\section{REFERENCES}

ALONZO, N.; HIRS, C.H.W. Automation of sample application in amino acid analyzers. Anal. Biochem. San Diego, v.23, n.2, p.272-278, 1968.

AMBLER, R.P. Enzymatic hydrolysis with carboxypeptidases. Methods Enzymology, New York, Academic Press, v.11, n.4, p. 155-166.

ARAI, S.; MAEDA, A.; MARSUMURA, M.; HIRAO, N.; WATANABE, M. Enlarged-scale production of a lowphenilalanine peptide substance as a foodstuff for patients with phenylketonuria. Agric. Biol. Chem., Tokyo, v.50, n.11,p.2929-2931, 1986.

BLAU, N.; SCRIVER, C.R. New approaches to treat PKU: Haw far are we? Mol. Genet. Metab., San Diego, v.81, n.1, p.1-2, 2004.

BOWERSOX, J. National Institutes of Health Consensus Development Panel. National Institutes of Health Consensus Developement Conference Statement. Phenylketonuria: screening and management. Pediatrics, Village, v.108, n.4, p.972-982, 2001.

CLEARY, M.A.; WALTER, J.H.; WRAITH, J.E.; JENKINS, J.P.; ALANI, S.M.; TYLER, K.; WHITTLE, D. Magnetic ressonance imaging of the brain in phenylketonuria. Lancet, London, v.344, n.9815, p.87-90, 1994.

CLEMENTE, A. Enzymatic protein hydrolysates in human nutrition. Trends Food Sci. Tecnol, London, v.11, n.7, p.254-262, 2000.

DAYHOFF, M. Atlas of protein sequence and structure. Washington: National Biomedical Research Foundation, Georgetown University Medical Center, 1972. p. 319-322.

ELSAS, L.J.; COSTA, P.B. Nutritional Support of Inherited Metabolic Disease. In: SHILS, ME.; OLSON, J.A.; SHIKE, M. Modern Nutrition in health and desease. 8 ed. Philadelphia: Lea \& Febiger, 1994. Cap. 67, p. 11471206.

FREITAS, O.; PADOVAN, G.J.; VILELA, L.; SANTOS, J.E.; DE OLIVEIRA, J.E.; GREENE, L.J. Characterization of protein hydrolysates prepared for enteral nutrition. J. Agri. Food Chem, Washington, v.41, n.3, p.1432-38, 1993. 
FREITAS, O.; IZUMI, C.; LARA, M.G.; GREENE, L.J. New approaches to the treatment of phenylketonuria. Nutr. Rev., Lawrence, v.57, n.3, p.65-69, 1999.

GREVER, L.C.; WHEELER, M.D.; GREENBURGESON, D.K.; ZORN, E.M. Breast feeding in the management of the new-born with phenylketonuria: a practical approach to dietary therapy. J. Am. Diet. Assoc., Chicago, v.94, n.3, p.305-309, 1994.

HEINDORFF, M.; BECKER, M.; SCHUSTER, W.; BRUEGMANN, F.; FIEDRICH, M. Manufature of phenylalanine-free protein hydrolisates, East German Patent DD 262, 674, 07/12/1988.

LOPEZ-BAJONERO, L.J.; LARA-CALDERON, P.; GALVEZ-MARISCAL, A.; VELASQUES-ARELLANO, A.; LOPEZ-MUNGUIA, A. Enzymatic production of a low-phenylalanine product from skim milk powder and caseinate. J. Food Sci., Chicago, v.56, n.4, p.938-942, 1992.

LUCAS, B.; SOTELO, A. Effect of different alkalis, temperature and hydrolysis time on tryptofan determination of pure proteins and of foods. Anal. Biochem., San Diego, v.109, n.1, p.192-197, 1980.

MATSUO, T.; HASHIMOTO, Y.; ARAI, S. Preparation of paptides with low content of phenylalanine for the treatment of phenylketonuria. Japonese Patent 6168426, 08/04/1986.
NAKHOST, Z.; HSIEH, D.S.T.; SHIH,V.; RHA, C.K. Synthesis of low-phenylalanine polypeptides. Int. J. Pept. Prot. Res., Copenhagen, v.20, n.3, p.267-275, 1982.

ROHR, F.J.; MUNIER, A.W.; LEVY, H.L. Acceptability of a new modular protein substitute for the dietary treatment of phenylketonuria. J. Inherit. Metab. Dis., Dordrecht, v.24, n.6, p.623-630, 2001.

SCRIVER, C.R.; KAUFMAN, S.; WOO, S.L.C. The hyperphenylalaninemias. In: The metabolic basis of inherited disease. 6 ed. Stanbury: McGraw Hill, 1989. p. 459-546.

SMITH, I. Treatment of phenylalanine hydroxylase deficiency. Acta Pediatr., Oslo, v. 407, p. S60-S65, 1994.

SPACKMAN, D.H.; STEIN, W.H.; MOORE, S. Automatic recording apparatus for use in the chromatography of amino acids. Anal. Chem., Washington, v.30, n.7, p. 1190206, 1958.

VSCONCELOS, A.M.H.; SANTOS NETO, A.L.C.; GRASSIANO, D.M.; OLIVEIRA, E.P.H. Adsorption chromatography of phenylalanine. Biotechnol. Bioeng., New York, v.33, n.10, p.1324-1329, 1989.

Recebido para publicação em 18 de outubro de 2004. Aceito para publicação em 30 de março de 2005. 